\title{
SPECIAL COURSES
}

Stephen Fischer-Galati has introduced a course dealing with the history of the Habsburg monarchy and the succession states at Wayne State University.

Arthur G. Haas, of the University of Tennessee, will conduct a seminar on the nationality problem in the Habsburg monarchy in the first half of the nineteenth century during the winter quarter of 1966.

Charles Jelavich is offering an undergraduate course in the history of the Habsburg empire from the eighteenth century to 1918 at Indiana University.

Miroslav Lablinka, of La Salle College, inaugurated a new course on Modern Eastern Europe in 1965-66 which will be primarily devoted to the history of the Austro-Hungarian empire and its successor states.

Woodford McClellan has introduced a course on the history of Eastern Europe during modern times at the University of Virginia.

William E. Wright is giving both a seminar on the Habsburg monarchy and a lecture course on modern Austria at the University of Minnesota.

\section{THE LEO BAECK INSTITUTE}

The Leo Baeck Institute (129 East 73rd Street, New York $21, N$. Y.) was founded in 1955 to retrace, collect, and preserve the experiences and achievements and gains and losses of all Jewish people living in German-speaking countries. Today the Institute has a library of more than 30,000 books. In addition, it has valuable archives and collections of rare documents and art objects. Many of these books and documents deal with Austrian Jewry. Several articles on Austrian Jews have been published in various Yearbooks of the Institute and others in its German-language Bulletins. The Institute also engages in historical research and publishes a monograph series. 